\title{
EFEKTIVITAS DAN PENGALAMAN PEMBELAJARAN DARING DI FAKULTAS PERTANIAN UNIVERSITAS ISLAM KALIMANTAN MUHAMMAD ARSYAD AL BANJARI BANJARMASIN
}

\author{
Aam Gunawan, Abd. Malik, M. Irwan Zakir, Ilhamiyah dan Ana Zuraida \\ Fakultas Pertanian, Universitas Islam Kalimantan \\ Email: aamgunawan@yahoo.com
}

\begin{abstract}
ABSTRAK
Kegiatan pengabdian kepada masyarakat ini bertujuan untuk meningkatkan efektivitas pembelajaran daring di Fakultas Pertanian Universitas Islam Kalimantan Muhammad Arsyad Al Banjari Banjarmasin untuk dosen dan mahasiswa di masa Covid 19. Metode yang dilakukan dalam kegiatan ini adalah presentasi dan tanya jawab menggunakan media Instagram, facebook, dan youtube yang dipandu oleh seorang moderator. Kegiatan pengabdian ini melibatkan seluruh dosen dan mahasiswa fakultas Pertanian ditambah dengan masyarakat umum yang tertarik dengan tema diskusi. Hasil kegiatan yang dilaksanakan selama satu jam pada media online ini menunjukkan bahwa follower yang terdiri dari dosen, mahasiswa dan masyarakat umum memberikan respon positif dan sangat termotivasi untuk segera meningkatkan efektivitas pembelajarannya secara maksimal.
\end{abstract}

Kata kunci: Efektivitas, Pembelajaran, Daring

\section{PENDAHULUAN}

Sejak wabah pandemik covid 19 melanda Indonesia pada bulan Maret 2020, Menteri Pendidikan dan Kebudayaan langsung mengambil langkah-langkah untuk mencegah penyebaran penyakit Covid 19 dan melindungi semua orang yang bergerak di bidang pendidikan, termasuk peserta didik, mahasiswa, dosen, dan tenaga kependidikan. Adapun langkah preventif yang dilakukan oleh Mendikbud adalah melakukan pembelajaran secara daring (dalam jaringan) menggunakan teknologi informasi internet. Keputusan pembelajaran daring ini tertuang dalam surat edaran nomor 36952/MPK.A/HK/2020 tentang Pembelajaran secara Daring dan Bekerja dari Rumah dalam Rangka Pencegahan Penyebaran Corona Virus Disease (COVID- 19).

Surat Keputusan Bersama 4 Menteri yang menyepakati bahwa proses pembelajaran khususnya di jenjang pendidikan tinggi pada semester gasal tahun akademik 2020/2021 di semua zona wajib diselenggarakan secara daring untuk mata kuliah teori. Sementara untuk mata kuliah praktik juga sedapat mungkin tetap dilakukan 
secara daring. Namun, jika menyangkut kelulusan dan kompetensi mahasiswa yang tidak dapat dilaksanakan secara daring maka kegiatan tersebut dapat diselenggarakan dengan tetap mengutamakan kesehatan dan keselamatan mahasiswa, dosen dan karyawan. Kegiatan praktikum dan penelitian di laboratorium dan studio bila memungkinkan diselenggarakan secara daring atau waktunya ditunda di bagian akhir semester atau semester berikutnya. Selanjutnya Mendikbud menerbitkan Panduan Penyelenggaraan Pembelajaran Semester Gasal 2020/2021 di Perguruan Tinggi untuk memberikan petunjuk penyelenggaraan pembelajaran secara daring.

Pelaksanaan keputusan pembelajaran daring tidaklah mudah untuk dilaksanakan, karena tidak semua perguruan tinggi di Indonesia mempunyai fasilitas yang lengkap guna menunjang pembelajaran daring ini. Oleh karena itu perlu dikaji tingkat efektivitas dari pembelajaran daring ini.

$$
\text { Efektivitas pembelajaran }
$$
merupakan suatu pembelajaran yang memungkinkan mahasiswa dapat belajar dengan mudah, menyenangkan, dan dapat mencapai tujuan pembelajaran. Indrawati dan Setiawan
(2009) memberikan penjelasan bahwa pembelajaran yang efektif adalah pembelajaran yang menghasilkan apa yang harus dikuasai siswa setelah proses pembelajaran berlangsung seperti dicantumkan dalam tujuan pembelajaran. Rohmawati (2015) mengungkapkan bahwa pembelajaran akan berjalan efektif apabila terdapat pembiasaan serta adanya kesesuaian antara visi dan misi, dalam mewujudkan pendidikan yang berkualitas. Oktavian dan Aldya (2020) menyatakan bahwa pembelajaran daring akan efektif jika menerapkan komponen esensial yang mencakup aspek diskursif, adaptif, interaktif, dan reflektif. Diskursif artinya memungkinkan diskusi antara siswa dan guru, di mana masing-masing mengungkapkan konsepsinya tentang beberapa aspek yang dijelaskan, dan bereaksi terhadap deskripsi yang lain; Adaptif artinya dimana, guru menyesuaikan interaksi siswa dengan lingkungan yang dialaminya; interaktif artinya memungkinkan siswa berinteraksi dengan cara meningkatkan pengalaman mereka; reflektif artinya dimana siswa merenungkan pengalaman dan menyesuaikan dengan konsepsi mereka sendiri beserta deskripsi mereka tentang hal tersebut. 
Keberhasilan dalam proses pembelajaran daring perlu ditunjang dengan latihan yang terus menerus, agar diperoleh pengalaman dalam penggunaan berbagai aplikasi yang digunakan. Demikian juga dengan siswa yang akan mengikuti ujian nasional berbasis komputer (UNBK) perlu dilatih agar tidak merasa asing menggunakan aplikasi UNBK dan computer yang digunakan. Herri Sulaiman dkk. (2020) membuat aplikasi tryout ujian nasional berbasis komputer secara online yang dicobakan di SMA Kabupaten Cirebon, dengan tujuan untuk membiasakan dan melatih siswa mengerjakan soal-soal UNBK secara online.

\section{METODE KEGIATAN}

\section{Metode Pelaksanaan Kegiatan}

Kegiatan pengabdian ini dilaksanakan secara daring dalam bentuk presentasi dan diskusi. Metode kegiatan yang dilaksanakan berupa:

(1) Pemberitahuan

Kegiatan pengabdian diawali dengan pemberitahuan dalam bentuk pembuatan foster yang disebarkan di seluruh media baik whatsApp, fecebook, maupun instagram. Pemberitahuan diumumkan 3 minggu sebelum pelaksanaan. Foster pengumuman disajikan pada Gambar 1.

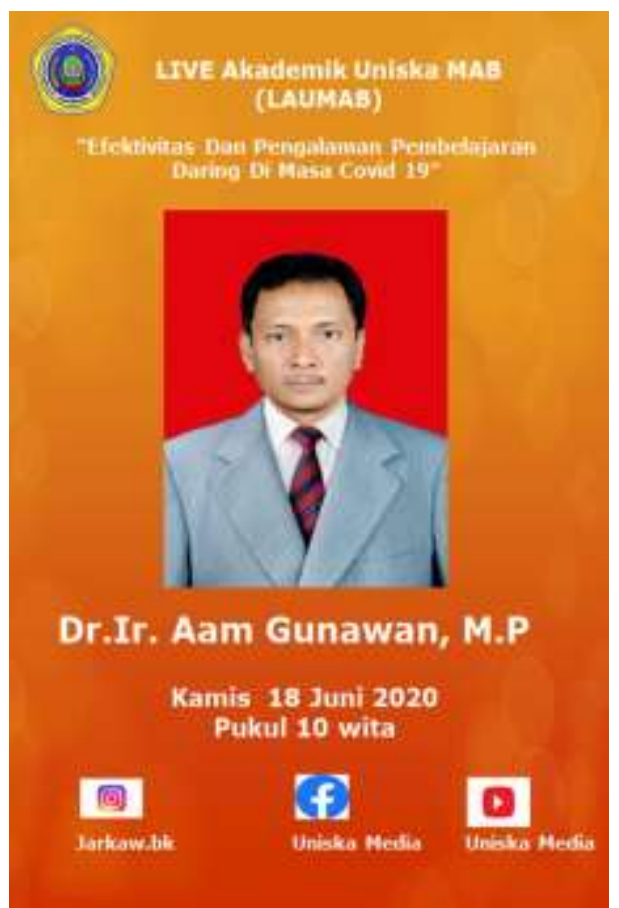

Gambar 1. Foster Pemberitahuan Pelaksanaan Pengabdian 
(2) Presentasi

Pelaksanaan kegiatan pengabdian dilakukan secara live pada tanggal 18 Juni 2020 pukul 10.00 wita, selama satu jam melalui media live akademik Uniska MAB (LAUMAB) yang bisa diakses melalui instagram, facebook dan youtube. Presentasi terlebih dahulu dibuka oleh moderator Bapak Dr. H. Ahmad Jarkawi, M.M.Pd. Selanjutnya pemaparan dialokasikan waktu 30 menit dan 30 menit berikutnya untuk diskusi. Pemaparan diawali dengan penjelasan tentang kebijakan pembelajaran daring di masa covid, pengertian efektifitas pembelajaran dan tujuan pembelajaran. Selanjutnya dijelaskan tentang pengalaman pembelajaran daring di Fakultas Pertanian Universitas Islam Kalimantan Muhammad Arsyad Al Banjari Banjarmasin.

(3) Tanya Jawab

Semua peserta yang turut bergabung dalam media live akademik Uniska MAB (LAUMAB) baik melalui instagram, facebook, dan youtube diberikan kesempatan untuk bertanya melalui chat yang telah tersedia pada media instagram, fecebook, dan youtube tentang sesuatu yang belum jelas, baik yang telah disampaikan dalam presentasi maupun hal-hal lain yang berkaitan dengan efektifitas dan pengalaman pembelajaran daring.

\section{KHALAYAK SASARAN}

Sasaran dari kegiatan pengabdian ini adalah para Dosen, Guru dan mahasiswa,. Selain itu juga kepada masyarakat umum yang peduli dengan pendidikan.

\section{HASIL} PELAKSANAAN

\section{KEGIATAN}

Hasil kegiatan yang terdiri dari presentasi dan tanya jawab tentang efektivitas dan pengalaman pembelajaran daring di Fakultas Pertanian Universitas Islam Kalimantan Muhammad Arsyad Al Banjari Banjarmasin, dapat terlaksana sesuai dengan rencana jadwal yang telah disusun dan hasil kegiatan tersebut dapat dijabarkan sebagai berikut:

Acara dimulai dengan pembukaan oleh Moderator Bapak Dr. H. Ahmad 
Jarkawi, M.M.Pd dan dilanjutkan dilanjutkan dengan penjelasan materi oleh pembicara utama, yaitu Dr. Ir. Aam Gunawan, M.P. Adapun materi yang diberikan meliputi latar belakang pembelajaran daring, pengertian efektifitas pembelajaran, tujuan pembelajaran, efektif tidaknya pembelajaran daring, model pembelajaran, dan pengalaman pembelajaran daring. Presentasi diikuti oleh para Dosen, Mahasiswa, dan masyarakat umum yang peduli dengan pendidikan. Berlangsung selama 30 menit dan dipandu oleh moderator (Gambar 2).

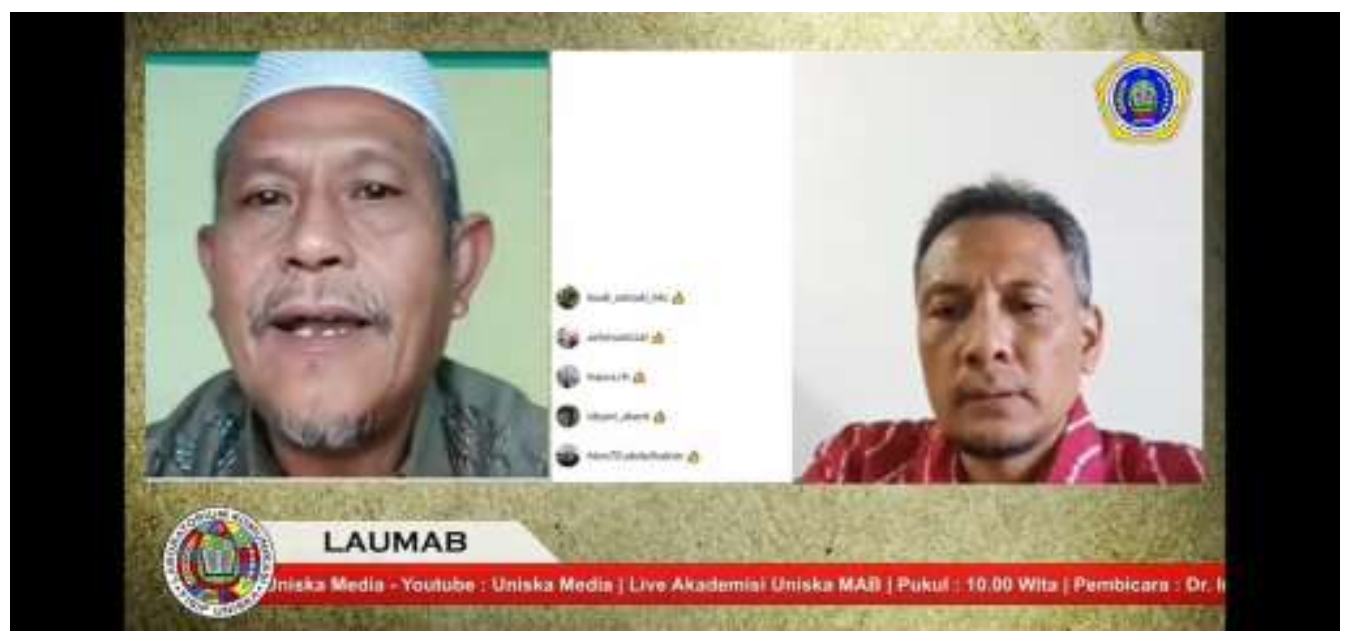

Gambar 2. Presentasi Live Dipandu Moderator

Secara ringkas materi yang disampaikan diawali dengan adanya Surat Mendikbud nomor 36952/MPK.A/HK/2020 tentang Pembelajaran secara Daring dan Bekerja dari Rumah dalam Rangka Pencegahan Penyebaran Corona Virus Disease (COVID- 19). (Kemendikbud, 2020). Kebijakan ini dirasakan berat bagi perguruan tinggi yang belum siap dengan sistem pembelajaran daringnya, namun demikian bila pembelajaran daring dilakukan dengan efektif, menunjukkan resistensi perguruan tinggi, artinya perguruan tinggi tetap eksis di tengah Covid19.

Efektivitas

pembelajaran merupakan suatu pembelajaran yang memungkinkan mahasiswa dapat belajar dengan mudah, menyenangkan, dan dapat mencapai tujuan pembelajaran. Tujuan pembelajaran merupakan kompetensi yang diharapkan dapat tercapai setelah mengikuti kegiatan pembelajaran (hasil belajar yang diharapkan). 
Beberapa alasan sistem pembelajaran daring dinilai tidak efektif adalah (1) Sistem pembelajaran daring hanya efektif untuk penugasan, untuk membuat mahasiswa memahami materi, cara daring dinilai sulit; (2) Tidak semua mahasiswa memiliki fasilitas yang menunjang kegiatan belajar daring. Koneksi lemot dan kuota internet yang mahal menjadi hambatan nyata; (3) Beberapa materi harus dijelaskan secara langsung; (4) Beberapa Dosen belum siap menggunakan OLM (Online Learning Model); dan (5) lemah pada sinyal jaringan internet. Agus Alim Muin dkk. (2019) menyimpulkan bahwa masih banyak peserta yang belum sepenuhnya memahami teknologi komputer.

$$
\text { Adapun kelebihan model }
$$
Pembelajaran daring adalah (1) Lebih praktis; (2) Bisa dilakukan dimana dan kapan saja; (3) untuk dosen yang membuat youtube bisa diputar berkali kali oleh mahasiswa sampai paham; (4) Tepat waktu dalam mengirim tugas; dan (5) lebih banyak waktu untuk belajar; dan (6) model pembelajaran :Konvensional (Tatap muka, face-toface leaning), Daring/ Online Learning Model (OLM)
Pengalaman pembelajaran daring yang sudah dilaksanakan di Fakultas Pertanian Universitas Islam Kalimantan diantaranya adalah perlu update dan upgrade materi supaya lebih menarik sehingga mahasiswa termotivasi untuk senantiasa belajar, mahasiswa belum mandi dan berpakaian tidak rapih, ada yang sambil menyetir, ada yang sambil bekerja (mengoperasi kucing), jadi mengenal berbagai aplikasi, di daerah terpencil mahasiswa berupaya mencari sinyal, naik ke tempat yang lebih tinggi atau pergi ke kota, kita bicara sendiri, mahasiswa tidak mendengar, akibat sinyal terputus, mahasiswa bisa gabung dalam aplikasi zoom tapi tidak fokus.

Setelah presentasi dilanjutkan dengan sesi diskusi. Hasil tanya jawab menunjukkan bahwa sebagian besar peserta sudah memahami tentang pembelajaran daring, namun agar pembelajaran daring ini efektif masih bingung, karena terkendala dengan jaringan dan fasilitas yang dimiliki mahasiswa. Beberapa pertanyaan yang dilontarkan diantaranya adalah:

a. Bagaimana caranya meningkatkan minat belajar?

b. Strategi pembelajaran daring supaya lebih efektif? 
c. Perencanaan, pelaksanaan, dan juga pada youtube melalui web: evaluasi seperti apa?

https://www.youtube.com/watch?v=PJ

d. Bagaimana dengan silabus $\underline{\text { GLheXQ1K0 }}$ pembelajaran daring?

Semua pertanyaan tersebut dapat dijelaskan dengan baik dan semua peserta merasa puas dengan penjelasan yang telah diberikan. Pertanyaan a dapat dijelaskan dengan mengacu pada panduan yang dikeluarkan oleh Direktorat Pembelajaran dan Kemahasiswaan (2020) memberikan penjelasan bahwa dalam pembelajaran daring Belajar mandiri adalah proses pembelajaran yang diinisiasi oleh peserta didik dalam periode tertentu. Untuk dapat membantu peserta didik belajar secara mandiri, dosen menyiapkan beragam tugas dan pemicu/inisiasi Belajar terbimbing adalah proses pembelajaran yang disediakan oleh perguruan tinggi untuk membantu proses belajar peserta didik dalam bentuk tutorial daring. Adapun yang dimaksud dengan tutorial daring proses pembelajaran jarak jauh yang dilaksanakan dengan mempersyaratkan adanya interaksi peserta didik dengan dosen/tutor, atau peserta didik dengan peserta didik yang termediasi oleh media berbasis TIK. Hasil pelaksanaan kegiatan pengabdian ini dapat diakses

\section{KESIMPULAN}

1. Dalam prakteknya, OLM tidak dirancang digunakan terpisah dari perkuliahan konvensional, namun digunakan secara sinergis bersama pembelajaran konvensional. OLM diposisikan sebagai pendukung perkuliahan mahasiswa karena pembelajaran daring murni belum dapat diterapkan secara penuh di sebagian besar perguruan tinggi di Indonesia.

2. Pembelajaran daring wajib dilakukan di semua perguruan tinggi di Indonesia untuk mencegah penyebaran covid 19, agar perguruan tinggi tidak menjadi cluster baru penyebaran covid 19 .

3. Pembelajaran daring perlu diefektifkan agar kompetensi yang diharapkan dapat tercapai

4. Efektivitas pembelajaran daring dapat ditingkatkan melalui: penyediaan sarana teknologi informasi, penyediaan sumber belajar elektronik, dan bantuan penyediaan kuota untuk mahasiswa. 


\section{DAFTAR PUSTAKA}

Agus Alim Muin, Sari Kumala, dan Erfan Karyadiputra. 2019. PKMS Peningkatan Kompetensi Guru dan Pengembangan Perangkat Pembelajaran Berbasis IT Guna Menunjang Pelaksanaan Kurikulum 2013 Pada SMP Negeri 1 Anjir Pasar Desa Anjir Pasar Kota II Kec. Anjir Pasar Kab. Batola. Jurnal Pengabdian Al-Ikhlas. Volume 5(1):78-86.

Direktorat Pembelajaran dan Kemahasiswaan, Direktorat Jenderal Pendidikan Tinggi Kemdikbud RI. 2020. Panduan Penyelenggaraan Pembelajaran Semester Gasal 2020/2021 di Perguruan Tinggi.

Herri Sulaiman, Trusti Hapsari, Tonah, dan Fuad Nasir. 2020. Simulasi Aplikasi Tryout Ujian Nasional Berbasis Komputer (Unbk) Online Di Sma Kabupaten Cirebon. Jurnal Pengabdian AlIkhlas. Volume 6(1):138-147

Indrawati dan W. Setiawan. 2009. Pembelajaran aktif, kreatif, efektif dan menyenangkan untuk Guru SD. Pusat Pengembangan dan
Pemberdayaan Pendidik dan Tenaga Kependidikan Ilmu Pengetahuan Alam (PPPPTKIPA) untuk Program Bermutu.

Kemendikbud. 2020. SE Mendikbud: Pembelajaran Secara Daring dan Bekerja dari Rumah untuk Mencegah Penyebaran Covid-19. https://www.kemdikbud.go.id/mai n/blog/2020/03/se-mendikbudpembelajaran-secara-daring-danbekerja-dari-rumah-untukmencegah-penyebaran-covid19. $\underline{10 / 06 / 2020}$.

Keputusan Bersama 4 Menteri Nomor 01/KB/2020 tanggal 15 Juni 2020 tentang Panduan Penyelenggaraan Pembelajaran pada Tahun Ajaran 2020/2021 dan Tahun Akademik 2020/2021 di Masa Pandemi Corona Virus Disease (Covid-19).

Oktavian, R. dan RF.Aldya. 2020. Efektivitas Pembelajaran Daring Terintegrasi Di Era Pendidikan 4.0. Jurnal Pendidikan dan Ilmu Pengetahuan. Volume 20(2):129135.

Rohmawati, A. 2015. Efektivitas Pembelajaran. Jurnal Pendidikan Usia Dini. Volume 9(1):15-32. 